\title{
INFLUENCES OF DIFFERENT DRYING CLIMATES ON Eucalyptus camaldulensis WOOD PROPERTIES
}

\author{
Ayşenur Kılıç Ak \\ https://orcid.org/0000-0002-3344-4551 \\ İbrahim Bektaş ${ }^{1}$ \\ https://orcid.org/0000-0002-0617-6926 \\ Mustafa Çiçekler ${ }^{1, \diamond}$ \\ https://orcid.org/0000-0001-5793-2827 \\ Ahmet Tutuş ${ }^{1}$ \\ https://orcid.org/0000-0003-2922-4916
}

\begin{abstract}
One of the most important disadvantages of the wood material, whose usage is becoming more and more widespread, is the dimensional instability that occurs in its interaction with water. Therefore, studies to improve these drawbacks of wood, remain always up to date. For the mentioned purpose in this study, some chemical, morphological, physical and mechanical properties of Eucalyptus camaldulensis woods, which were naturally dried in outdoor and indoor climate in Eastern Mediterranean (Kahramanmaraş province) atmosphere conditions of Turkey, were investigated. According to the results of the study, chemical properties of Eucalyptus woods dried indoor were measured as merely $0,23 \%$ higher than dried ones outdoor. The results of morphological measurements indicated that the fiber dimensions of eucalypt wood dried in indoor were average $1,48 \%$ lower than the ones dried out outdoor. Also, as a result of statistical analysis, it was found that there were significant differences $(\rho<0,000)$ between the physical properties of Eucalyptus wood samples indoor and outdoor according to the t-test. At the same time, as a result of the t-test applied to determine the effect of drying conditions on mechanical properties of Eucalyptus wood, modulus of elasticity, compression, tensile, dynamic bending and shear strength did not cause any significant difference between indoor and outdoor, while bending and Janka hardness strengths showed significant differences at $\rho<0,000$ level. Finally, when the data obtained as a whole is considered, it can be said that testing of Eucalyptus wood which requires a very sensitive drying in different climates has important contributions on the subject. Regarding eucalypts, which has a high distribution area (20 million hectares) in the world, it is recommended to relevant institutions and organizations to expand and maintain such study in the future. Lastly, according to obtained data from this study, it can be said that the experiments of Eucalyptus woods which require a very delicate drying in different environments provide important contributions on the subject.
\end{abstract}

Keywords: Basic density, chemical properties, morphological properties, mechanical properties, shrinkage. 


\section{INTRODUCTION}

One the most important disadvantages is the change in the dimensions of wood material during its interaction with water. As a result of the reduction of wood-based resources, demand for wood cannot be adequately met and price increases are higher than expected. For these and similar reasons, the studies on reducing the objectionable aspects of the wood material and increasing their positive properties are always keep up-to-date (Kocaefe et al. 2008, Aytin et al. 2015, Cetin and Gunduz 2016).

As is known, wood is an anisotropic material and its properties differ in various directions (Dahl and Malo 2009, Dackermann et al. 2016). Knowing of the physical, mechanical and chemical properties of wood makes it easier to compare wood materials with others and gives ideas about processing and usage characteristics (Sancak 2010, Duzkale et al. 2014, Cetin and Gunduz 2017). Mechanical properties are defined as the degree and condition of the wood to resist external forces and various types of loads, such as mechanical and external forces, which lead to dimension and deformation, stress and rupture (Bozkurt and Goker 1996). Due to its hygroscopic properties, wood material or any wood-based product can reach certain equilibrium moisture content by adapting to weather conditions in various places of use. In dimensions of wood material, which is not dried sufficiently changes occurs such as shrinkage or swelling during utilization (Kantay 1993, Bergman 2021). Because of these changes, defects such as cracking, separation from joints, and deformation of wood material can take place (Ors and Keskin 2008). There are two main components in wood: lignin (18 \% - $35 \%)$ and carbohydrates (cellulose and hemicellulose) (Ors and Keskin 2008). These components are complex and polymeric materials. There are minor extraneous materials in structure of wood, which are organic extractives and inorganic minerals (ash). Generally, wood has an elemental composition of about $50 \%$ carbon, $6 \%$ hydrogen, $44 \%$ oxygen, and trace amounts of several metal ions (Pettersen 1984).

Australia is the homeland of the genus Eucalyptus. Eucalyptus camaldulensis is cultivated for commercial purposes in Turkey and this plant of foreign origin has become native (Davis 1988). Eucalypts, which is grown especially in the southern regions of Turkey, is a type of tree that has an important role for forest industry in the world due to its large diameter arises in a short time and has smooth trunk. This plant, which has been grown in Turkey since 1939, obtains different forest products for various purposes, primarily for railroad tie and bridge production, followed by cellulose, which is the raw material of paper industry (Karsavuran 2008). Eucalyptus, which was considered as a packing case at first, is nowadays used in many areas such as building constructions, veneer, furniture, chest, turnery, agricultural tools, musical instruments, sports equipment, stull, trolley pole and fiber-chip wood (Yaltirik and Efe 1994, Korkut et al. 2008).

The water present in new-cut trees should be eliminated from wood before using as end product. Hence, rough and fresh timber should be exposed to drying process. Depending on species, weather conditions, timber dimensions and the season when the wood piled, natural-drying times vary widely. Temperature, relative humidity and airflow effect the drying process of wood piles (Bektas et al. 2017). Different timber dimensions, bark content and piling specifications may strongly affect natural-drying times (Simpson and Wang 2004, Bown and Lasserre 2015). The drying process has several important advantages such as increases some strength properties and improves dimensional stability of wood (Forest Products Laboratory 1999). However, drying defects such as cracks, hardening, cell collapse, shape changes, color changes adversely affect the quality of the wood material (Kantay 1993).

As far as can be researched, no studies have encountered effect of different drying climates on the properties of Eucalyptus wood. Closest to the subject of this study, mechanical properties of Eucalyptus urophylla wood (Lahr et al. 2017) and Eucalyptus grandis wood (Lahr et al. 2018) of different moisture (12\%, $30 \%)$ levels were investigated. Eventually, Lahr et al. (2018) found that mechanical properties were significantly affected by moisture content, and the behavior pattern consisted in increasing the values of the properties with reduction of moisture content. Other researchers also investigated Eucalyptus saligna (Nogueira et al. 2019) and Eucalyptus maidenii wood's properties in abovementioned moisture contents (Nogueira et al. 2018). In another study, pine (Pinus sylvestris) and beech (Fagus sylvatica) woods were subjected to steam kiln-drying. Modulus of elasticity and bending strength for steam dried, air-steam mixture dried and air-dried samples as reference were measured. They concluded that steam and air-steam mixture drying cause changes of the mechanical properties of analyzed wood species (Baranski et al. 2014).

In the light of the above explanations, the effects of natural drying climates on some chemical, morphological, physical and mechanical properties of Eucalyptus wood, one of the fast growing tree species with high distribution areas, was investigated in this study. 


\section{MATERIALS AND METHODS}

\section{Materials}

The freshly sawn lumbers were obtained from Mersin-Karabucak Forest Sub-district Directorate. Lumbers were cut into the dimensions of $6 \mathrm{~cm} \times 15 \mathrm{~cm} \times 300 \mathrm{~cm}$ and the ends of edged timbers were not sealed. When the timbers were brought to drying environments, their starting moisture content (MC) varied between $57 \%$ to $72 \%$. Twenty timbers were dried in each environment in order to minimize random variations and the test samples were randomly selected from the piles.

\section{Drying process}

Air drying method was applied to the timbers stacked in Kahramanmaraş Province. Timbers were piled in two different environments: Outdoor (OD) and Indoor (ID). Drying process was began in summer period (effective drying) on June and followed during one year. The data were taken from meteorological station for OD and Geratech DT-172 was used to measure temperature and relative humidity of ID.

\section{Determination of physical and mechanical properties}

Test specimens were obtained from eucalypts (Eucalyptus camaldulensis Dehnh.) timbers supplied in Mersin-Karabucak territory. Test specimens were prepared on the basis of TS 2470 (1976). Some physical properties such as air-dry density, oven-dry density and basic density values were determined with the sample dimension of $20 \mathrm{~mm} \times 20 \mathrm{~mm} \times 30 \mathrm{~mm}$, based on TS 2472 (1976). Additionally, volumetric shrinkage and swelling was calculated according to TS 4083 (1983), TS 4084 (1983), TS 4085 (1983), TS 4086 (1983) with the sample dimension of $20 \mathrm{~mm} \times 20 \mathrm{~mm} \times 30 \mathrm{~mm}$. As for the mechanical properties, static bending strength and modulus of elasticity was designated on the sample dimensions of $20 \mathrm{~mm} \times 20 \mathrm{~mm} \times 300 \mathrm{~mm}$ based on TS 2474 (1976) and TS 2478 (1976), respectively. With the same sample size, dynamic bending strength was also calculated according to TS 2477 (1976). Furthermore, compression strength parallel to grain $(20 \mathrm{~mm} \times 20$ $\mathrm{mm} \times 30 \mathrm{~mm})$, Janka hardness $(50 \mathrm{~mm} \times 50 \mathrm{~mm} \times 50 \mathrm{~mm})$, tensile and shear strength samples were prepared for the laboratory experiment and strength values were determined TS ISO 13061-17 (2019), TS 2479 (1976), TS 2475 (1976) and TS 3459 (2012), respectively.

The Independent Samples t-test was performed to determine if there were statistically significant differences between the properties of ID and OD dried wood.

\section{Determination of chemical and morphological properties}

Eucalyptus samples were chipped to matchstick size and in order to determine chemical components, chips were ground in a laboratory type Wiley mill according to TAPPI T257 om-85 standard. Samples passing through 40-mesh sieve and remaining over 60-mesh sieve were stored in closed containers for chemical analysis and moisture contents were determined. Holocellulose, cellulose, alpha cellulose, lignin, extractive and ash contents of the samples were determined according to Wise and Karl (1962), Kurschner and Hoffer (1969), TAPPI T203 cm-99 (1999), TAPPI T222 om-15 (2015), ASTM D1107-96 (2013) and TAPPI T211 om-16 (2016), respectively. Cold water, hot water and $1 \% \mathrm{NaOH}$ solubilities of the samples were determined according to TAPPI T207 cm-08 (2008) and TAPPI T212 om-18 (2018) standards.

The maceration process was carried out with chlorite method to make the woody fibers individual. Fiber slides were prepared for determination of fiber dimensions by using Nikon FS1 photo microscope; the average fiber width, length, lumen diameter, and cell wall thickness of 100 fibers were measured. 


\section{RESULTS AND DISCUSSION}

The results obtained from the experiments on the chemical contents of Eucalyptus wood dried in indoor and outdoor conditions are given in Table 1.

Table 1: Chemical compositions and solubilities of dried Eucalyptus camaldulensis samples under different climates.

\begin{tabular}{|c|c|c|c|}
\hline $\begin{array}{c}\text { Chemical components } \\
\text { and solubilities }\end{array}$ & $\begin{array}{c}\text { Indoor (ID) } \\
(\%)\end{array}$ & $\begin{array}{c}\text { Outdoor (OD) } \\
(\%)\end{array}$ & $\begin{array}{c}\text { Difference (ID - OD) } \\
(\%)\end{array}$ \\
\hline $\begin{array}{c}\text { Toluene-Acetone- } \\
\text { Ethanol solubility }\end{array}$ & 12,8 & 12,8 & 0,00 \\
\hline $1 \%$ NaOH solubility & 23,4 & 23,5 & $-0,10$ \\
\hline Cold water solubility & 11,1 & 11,7 & $-0,60$ \\
\hline Hot water solubility & 15,6 & 14,9 & 0,70 \\
\hline Ash content & 0,24 & 0,21 & 0,03 \\
\hline Holocellulose content & 77,4 & 77,9 & $-0,50$ \\
\hline Cellulose content & 48,2 & 47,8 & 0,40 \\
\hline Alpha cellulose content & 47,5 & 47,1 & 0,40 \\
\hline Lignin content & 35,2 & 35,3 & $-0,10$ \\
\hline Sum of differences & - & - & 0,23 \\
\hline
\end{tabular}

According to Table 1, toluene-acetone-ethanol solubilities and lignin contents of Eucalyptus wood dried ID and OD were found to be similar. Hot-water solubility of woods dried OD is lower than that of ID. The coldwater solubility of OD dried Eucalyptus wood was about 5,1\% lower than that of the ID. The holocellulose content of the OD dried wood was 0,5 units higher than that of the ID. In terms of cellulose and alpha cellulose contents, woods dried ID are richer than woods dried OD. When Table 1 is examined in general, there are significant differences between water solubility values of Eucalyptus wood dried ID and OD climates, but there is no significant difference between other chemical components and solubilities. Ayata (2008) determined holocellulose and lignin contents of Eucalyptus grandis wood as $81,2 \%$ and 25,7 \%, respectively. In the same study, ash and extractives contents were found to be $0,3 \%$ and $2,4 \%$. It was found that holocellulose content was lower and lignin and extractive contents were higher than those of undried Eucalyptus wood.

Table 2 indicates the differences revealed in fiber dimensions of Eucalyptus samples dried in ID and OD climates.

Table 2: Fiber morphological properties of Eucalyptus woods dried under different climates.

\begin{tabular}{|c|c|c|c|}
\hline Fiber dimensions & ID & OD & Difference (ID - OD) \\
\hline Fiber length $(\mathrm{mm})$ & 0,81 & 0,82 & $-0,01$ \\
\hline Fiber width $(\mu \mathrm{m})$ & 14,9 & 15,7 & $-0,80$ \\
\hline Lumen diameter $(\mu \mathrm{m})$ & 3,26 & 3,78 & $-0,52$ \\
\hline Cell wall thickness $(\mu \mathrm{m})$ & 5,79 & 5,94 & $-0,15$ \\
\hline Sum of differences & - & - & $-1,48$ \\
\hline
\end{tabular}

When fiber dimensions of Eucalyptus woods dried in different climates are examined, it is seen in Table 2 that there are no differences between fiber lengths and cell wall thicknesses. The most significant difference is in fiber width, and wood dried OD is about $5,4 \%$ wider than the one dried ID. Likewise, lumen diameter of wood dried OD was found to be wider 0,52 units than that of dried ID. It can be thought that these differences can be occurred due to relative humidity of OD climate being higher than that of ID. In the literature, no study has been found on the effects of drying climates on fiber morphological properties. However, it is seen that 
the fiber dimensions of the samples dried in both conditions are similar with the literature (Bhat et al. 1990, Gurboy and Ozden 1994, Trevisan et al. 2017).

Statistical analysis data of air-dry, oven-dry and basic density values are given in Table 3.

Table 3: Densities values of the samples dried in ID and OD climates.

\begin{tabular}{|c|c|c|c|c|c|c|c|c|}
\hline Properties & $\mathrm{DC}$ & $\mathrm{N}$ & $\begin{array}{c}\text { Mean } \\
\left(\mathrm{kg} / \mathrm{m}^{3}\right)\end{array}$ & SD & $\mathrm{SE}$ & $\begin{array}{l}\text { CV } \\
(\%) \\
\end{array}$ & $\mathrm{t}_{\text {value }}$ & $\begin{array}{c}\text { Sig. } \\
\text { (2-tailed) }\end{array}$ \\
\hline \multirow{2}{*}{ Air-dry density } & ID & 27 & 680 & 49,8 & 9,6 & 7,32 & \multirow{2}{*}{4,583} & \multirow{2}{*}{0,000} \\
\hline & OD & 27 & 754 & 67,2 & 12,9 & 8,92 & & \\
\hline \multirow{2}{*}{ Oven density } & ID & 27 & 585 & 41,6 & 8,0 & 7,11 & \multirow{2}{*}{5,620} & \multirow{2}{*}{0,000} \\
\hline & OD & 27 & 664 & 59,9 & 11,5 & 9,02 & & \\
\hline \multirow{2}{*}{ Basic density } & ID & 27 & 535 & 40,3 & 7,8 & 7,52 & \multirow{2}{*}{$-4,021$} & \multirow{2}{*}{0,000} \\
\hline & OD & 27 & 588 & 55,3 & 10,6 & 9,40 & & \\
\hline
\end{tabular}

DC: Drying climate, N: Number of samples; SD: Standard deviation, SE: Standard error, CV: Coefficient of variation.

According to data in Table 3, differences of drying condition on air-dry density, oven-dry density and basic density values were found to be significant at $\rho<0,000$ level. In same table, it can be seen that the air-dry density, oven-dry density and basic density values of the samples dried in OD were higher than those of dried in ID. These increases were determined as $10,88 \%$ in air-dry density, $13,50 \%$ in oven-dry density and 9,91 $\%$ in basic density. In a study conducted in the literature, air-dry density, oven-dry density and basic density values were found as $670 \mathrm{~kg} / \mathrm{m}^{3}, 620 \mathrm{~kg} / \mathrm{m}^{3}, 510 \mathrm{~kg} / \mathrm{m}^{3}$, respectively (Aslan et al. 2008). In another study performed between two different types of Eucalyptus, these values were found to be $530 \mathrm{~kg} / \mathrm{m}^{3}, 520 \mathrm{~kg} / \mathrm{m}^{3}$, $460 \mathrm{~kg} / \mathrm{m}^{3}$ for Eucalyptus grandis. and $700 \mathrm{~kg} / \mathrm{m}^{3}, 680 \mathrm{~kg} / \mathrm{m}^{3}, 570 \mathrm{~kg} / \mathrm{m}^{3}$ for Eucalyptus camaldulensis Dehn., respectively (Ayata 2008). The results obtained from this study are similar with the literature.

Shrinkage values made to determine the dimensional stability of the Eucalyptus wood dried in ID and OD conditions are given in Table 4.

Table 4: The shrinkage values of the samples dried in ID and OD.

\begin{tabular}{|c|c|c|c|c|c|c|c|c|}
\hline $\begin{array}{c}\text { Measurement } \\
\text { direction }\end{array}$ & $\mathrm{DC}$ & $\mathrm{N}$ & $\begin{array}{c}\text { Mean } \\
(\%)\end{array}$ & SD & SE & $\begin{array}{l}\text { CV } \\
(\%)\end{array}$ & $t_{\text {value }}$ & $\begin{array}{c}\text { Sig. } \\
\text { (2-tailed) }\end{array}$ \\
\hline \multirow{2}{*}{ Radial } & ID & 40 & 5,24 & 5,140 & 0,813 & 98,14 & \multirow{2}{*}{0,183} & \multirow{2}{*}{0,855} \\
\hline & OD & 40 & 5,08 & 1,552 & 0,245 & 30,55 & & \\
\hline \multirow{2}{*}{ Tangential } & ID & 40 & 5,01 & 1,398 & 0,221 & 27,94 & \multirow{2}{*}{$-3,688$} & \multirow{2}{*}{0,000} \\
\hline & OD & 40 & 5,97 & 0,896 & 0,142 & 15,00 & & \\
\hline \multirow{2}{*}{ Longitudinal } & ID & 40 & 0,65 & 0,738 & 0,117 & 113,32 & \multirow{2}{*}{$-1,382$} & \multirow{2}{*}{0,169} \\
\hline & OD & 40 & 0,85 & 0,566 & 0,090 & 66,28 & & \\
\hline \multirow{2}{*}{ Volumetric } & ID & 40 & 10,89 & 5,224 & 0,826 & 47,95 & \multirow{2}{*}{1,169} & \multirow{2}{*}{0,246} \\
\hline & OD & 40 & 11,91 & 1,724 & 0,273 & 14,47 & & \\
\hline
\end{tabular}

As it can be seen in Table 4, tangential shrinkage values constitute significant differences $(\rho<0,000)$ between Eucalyptus timber dried in ID and OD climates, however in radial, longitudinal and volumetric shrinkage values did not demonstrate same trend.

When shrinkage percentages of the samples dried in ID and OD were evaluated, radial shrinkage showed a decrease of approximately $3 \%$ in OD $(5,08 \%)$ measurements compared to ID $(5,24 \%)$. Tangential and longitudinal shrinkage values of samples dried ID were found to be lower about $19 \%$ and $30,8 \%$ than those of samples dried OD, respectively. Finally, volumetric swelling is less with a rate of $9,4 \%$ compared in ID climate $(10,89 \%)$ to OD $(11,91 \%)$. All shrinkage and deformations in the wood, from cutting to usage area, are the main reasons why the need to be dried before use (Kilic Ak 2016). In this study, volumetric swelling results (ID: 10,89 \%, OD: 11,91 \%) different when compared from other species of Eucalyptus: lower than that mentioned by Lima et al. (2014) for Eucalyptus resinifera (16,67 \%), by As et al. (2001) for Eucalyptus rostrata $(12,7 \%)$. Moreover, similar results were found for Eucalyptus camaldulensis as 11,4 \% and 11,8 \% 
(Aslan et al. 2008, Ay et al. 2008).

Table 5 shows percentages of swelling calculated in Eucalyptus samples dried in ID and OD climates.

Table 5: The swelling values of the samples dried in ID and OD.

\begin{tabular}{|c|c|c|c|c|c|c|c|c|}
\hline $\begin{array}{c}\text { Measurement } \\
\text { direction }\end{array}$ & $\mathrm{DC}$ & $\mathrm{N}$ & $\begin{array}{c}\text { Mean } \\
(\%)\end{array}$ & $\mathrm{SD}$ & SE & $\begin{array}{l}\text { CV } \\
(\%)\end{array}$ & $\mathrm{t}_{\text {value }}$ & $\begin{array}{c}\text { Sig, } \\
\text { (2-tailed) }\end{array}$ \\
\hline \multirow{2}{*}{ Radial } & ID & 40 & 9,07 & 3,078 & 0,487 & 33,94 & \multirow{2}{*}{1,476} & \multirow{2}{*}{0,144} \\
\hline & OD & 40 & 8,04 & 3,163 & 0,500 & 39,34 & & \\
\hline \multirow{2}{*}{ Tangential } & ID & 40 & 7,59 & 1,734 & 0,274 & 22,85 & \multirow{2}{*}{$-5,198$} & \multirow{2}{*}{0,000} \\
\hline & OD & 40 & 9,57 & 1,675 & 0,265 & 17,50 & & \\
\hline \multirow{2}{*}{ Longitudinal } & ID & 40 & 0,75 & 0,537 & 0,085 & 71,87 & \multirow{2}{*}{$-3,231$} & \multirow{2}{*}{0,002} \\
\hline & OD & 40 & 1,29 & 0,909 & 0,144 & 70,69 & & \\
\hline \multirow{2}{*}{ Volumetric } & ID & 40 & 17,41 & 3,030 & 0,479 & 17,41 & \multirow{2}{*}{1,837} & \multirow{2}{*}{0,070} \\
\hline & OD & 40 & 18,90 & 4,153 & 0,657 & 21,98 & & \\
\hline
\end{tabular}

According to the results of t-tests applied to swelling measurements presented in Table 5, tangential and longitudinal swelling values have significant differences in terms of drying climate, whereas the effect of climate is found to be insignificant on the radial and volumetric swelling percentages. When swelling values of the samples dried in OD compared with ID, a decrease of approximately $11,4 \%$ was observed in the radial direction, whereas in increase was observed $26,1 \%$ in the tangential, $72 \%$ in the longitudinal direction and $8,6 \%$ in the volumetric dimension. The values found for volumetric swelling were determined to be lower to those reported in the literature (Aslan et al. 2008, Ay et al. 2008). From these results, it can be said that a more protective drying was performed in ID climates.

Mechanical properties and statistical analysis of the wood samples dried in ID and OD climates are presented in Table 6.

Table 6: The mechanical properties the samples dried in ID and OD.

\begin{tabular}{|c|c|c|c|c|c|c|c|c|c|}
\hline \multicolumn{2}{|c|}{$\begin{array}{l}\text { Mechanical } \\
\text { properties }^{(*)}\end{array}$} & $\mathrm{DC}$ & $\mathrm{N}$ & $\begin{array}{l}\text { Mean } \\
(\mathrm{MPa})\end{array}$ & $\mathrm{SD}$ & $\mathrm{SE}$ & $\begin{array}{c}\text { COV } \\
(\%) \\
\end{array}$ & $t_{\text {value }}$ & $\begin{array}{c}\text { Sig, } \\
\text { (2-tailed) }\end{array}$ \\
\hline \multirow{2}{*}{\multicolumn{2}{|c|}{$\sigma_{\mathrm{CS} / /}$}} & ID & 50 & 53,18 & 7,026 & 0,994 & 13,21 & \multirow{2}{*}{0,829} & \multirow{2}{*}{0,409} \\
\hline & & OD & 50 & 52,03 & 6,890 & 0,974 & 13,24 & & \\
\hline \multirow{2}{*}{\multicolumn{2}{|c|}{$\sigma_{\mathrm{SBS}}$}} & ID & 28 & 83,39 & 7,783 & 1,471 & 9,33 & \multirow{2}{*}{$-2,076$} & \multirow{2}{*}{0,043} \\
\hline & & OD & 28 & 92,10 & 20,794 & 3,930 & 22,58 & & \\
\hline \multirow{2}{*}{\multicolumn{2}{|c|}{ MOE }} & ID & 28 & 6915,2 & 740,20 & 139,89 & 10,70 & \multirow{2}{*}{$-1,712$} & \multirow{2}{*}{0,093} \\
\hline & & OD & 28 & 7444,3 & 1458,59 & 275,65 & 19,59 & & \\
\hline \multirow{2}{*}{\multicolumn{2}{|c|}{$\sigma_{\mathrm{TS} / /}$}} & ID & 33 & 74,14 & 15,251 & 2,655 & 20,57 & \multirow{2}{*}{$-0,245$} & \multirow{2}{*}{0,807} \\
\hline & & OD & 33 & 75,26 & 21,421 & 3,729 & 28,46 & & \\
\hline \multirow{2}{*}{\multicolumn{2}{|c|}{$\sigma_{\mathrm{DBS}}$}} & ID & 27 & 0,51 & 0,208 & 0,040 & 40,82 & \multirow{2}{*}{1,111} & \multirow{2}{*}{0,272} \\
\hline & & OD & 27 & 0,46 & 0,114 & 0,022 & 24,77 & & \\
\hline \multirow{2}{*}{\multicolumn{2}{|c|}{$\sigma_{\mathrm{SS} / /}$}} & ID & 36 & 9,93 & 1,422 & 0,237 & 14,32 & \multirow{2}{*}{$-0,839$} & \multirow{2}{*}{0,404} \\
\hline & & OD & 36 & 10,25 & 1,786 & 0,298 & 17,42 & & \\
\hline \multirow{6}{*}{ 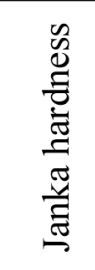 } & \multirow{2}{*}{$\mathrm{C}_{\mathrm{rs}}$} & ID & 30 & 81,36 & 16,574 & 3,026 & 20,37 & \multirow{2}{*}{$-5,418$} & \multirow{2}{*}{0,000} \\
\hline & & $\mathrm{OD}$ & 50 & 103,21 & 17,971 & 2,542 & 17,41 & & \\
\hline & \multirow{2}{*}{$\mathrm{R}$} & ID & 30 & 72,91 & 17,900 & 3,268 & 24,55 & \multirow{2}{*}{$-5,613$} & \multirow{2}{*}{0,000} \\
\hline & & OD & 50 & 98,18 & 20,374 & 2,881 & 20,75 & & \\
\hline & \multirow{2}{*}{$\mathrm{T}$} & ID & 30 & 78,46 & 15,610 & 2,850 & 19,90 & \multirow{2}{*}{$-4,363$} & \multirow{2}{*}{0,000} \\
\hline & & OD & 50 & 97,21 & 20,171 & 2,853 & 20,75 & & \\
\hline
\end{tabular}

${ }^{(*)} \sigma_{\mathrm{CS} / /}$ : Compression strength parallel to grain, $\sigma_{\mathrm{SBS}}$ : Static bending strength, MOE: Modulus of Elasticity, $\sigma_{\mathrm{TS} /:}$ : Tensile strength parallel to grain, $\sigma_{\mathrm{DBS}}:$ Dinamic bending strength, $\sigma_{\mathrm{SS} /:}:$ Shear strength, $\mathrm{C}_{\mathrm{rs}}:$ Cross section, R: Radial section, T: Tangential section. 
The results of the t-test given in Table 6, which were applied to reveal effect of ID and OD drying climates showed differences on mechanical properties. Significant differences were found between the bending strength and modulus of elasticity of the samples dried in ID and OD climates according to t-test results at $\rho<0,050$ significance level. Likewise, Janka hardness values measured in cross sectional, radial and tangential directions constituted significant differences at $\rho<0,000$ level according to ID and OD drying climates. T-test results introduced that there is no significant effect of drying climate differences on compression, tensile, dynamic bending and shear strength samples. On the other hand, calculations based on data in Table 6 revealed that the compression strength and dynamic bending strength for the samples dried in OD were 2,3\% and 9,8\% lower than those dried in ID, respectively. However, the modulus of elasticity, static bending strength, tensile strength and shear strength values of the samples dried in ID were determined as 8,6 \%, 11,3\%, 0,80\% and 2,11\% lower than those of dried in OD climates, respectively.

As it can be seen from Table 6, effect of drying climates difference on the tensile strength parallel to the fibers was calculated as much lower $(0,80 \%)$ than OD climate, in contrast to the compressive and bending strengths. Another interesting data is also that the dynamic bending strength value of samples $(0,51 \mathrm{MPa})$ dried in ID climate is approximately $10 \%$ higher than the other one $(0,46 \mathrm{MPa})$. Since dynamic bending strength is particularly prominent for using structural wood in the seismic zones, the effect of the drying environment difference in such usage areas should be take into account. Regarding Janka hardness values, it can be seen from the data in Table 6 that the difference between the samples dried in OD and ID is much higher than other mechanical properties. The Janka hardness values measured in ID all three directions $\left(\mathrm{C}_{\mathrm{rs}}, \mathrm{R}, \mathrm{T}\right)$ are lower than those measured in the OD. These decreases were calculated as $12,17 \%, 25,74 \%$ and $19,29 \%$ according to $\mathrm{C}_{\mathrm{rs}}$, $\mathrm{R}$ and $\mathrm{T}$ directions, respectively. There are many studies on the mechanical properties of Eucalyptus woods in the literature; however, there have been any research dealing with the differences in drying climates (Aslan et al. 2008, Ay et al. 2008, Bektas et al. 2008).

On the other hand, temperature and relative humidity, which are two of main drying factors of environment where this research was carried out, were investigated by Kilic Ak (2016) and obtained data are illustrated in Figure 1. The most effective period for fast drying is summer period called "effective drying period". This period is between intersection points of curves showing the change of air temperature and relative humidity within one year at place of drying (Kantay 1993). The effective drying periods were indicated in Figure 1 with arrows.

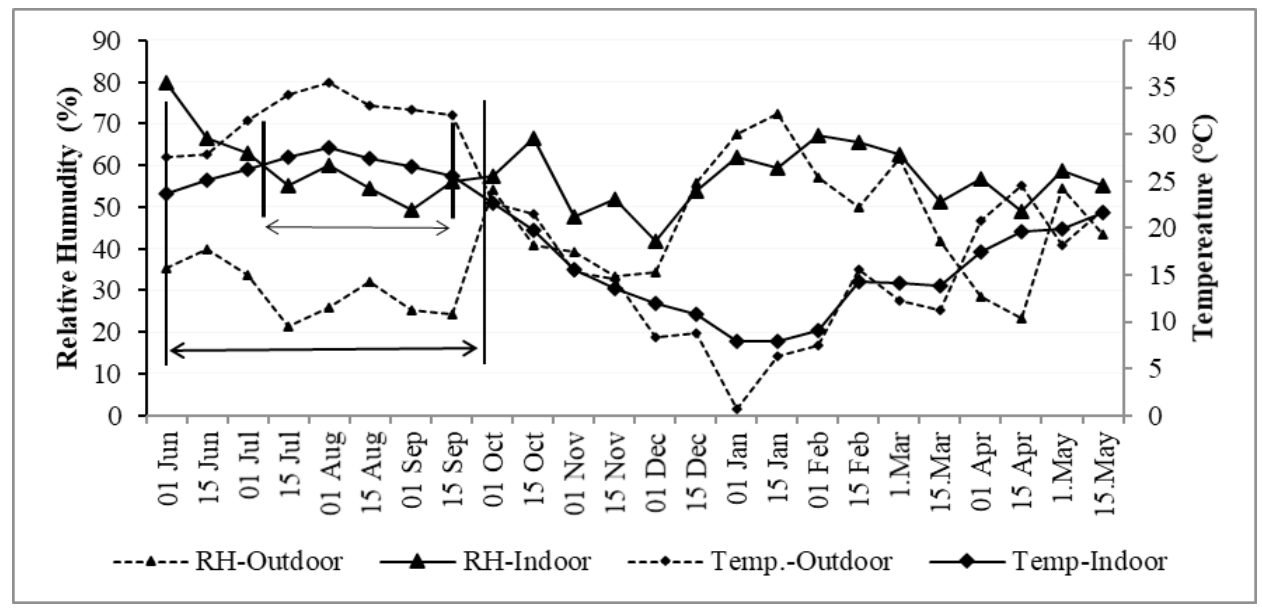

Figure 1: Temperature and relative humidity values of different climates.

According to Figure 1, the temperature in summer is higher in OD than ID, but it is lower in winter. Relative humidity values are generally higher in ID than those of in OD. It is understood from Figure 1 that the fastest drying in both (ID, OD) climate took place between June and September, when the temperature was higher and the relative humidity was lower. Furthermore, these data indicate that the effective drying period in Kahramanmaraş province occurred between June and September. 


\section{CONCLUSIONS}

The results of the tests to investigate effect of drying climate on the chemical, morphological, physical and mechanical properties of Eucalyptus woods can be summarized as follows;

There was no significant difference between the chemical compositions of Eucalyptus woods dried in ID and OD. The fiber width and lumen diameters of the wood dried in OD were wider than those of dried in ID due to differences relative humidity.

As a result of the physical tests, significant differences were found between the air-dry and oven-dry density, basic density, tangential shrinkage, tangential and longitudinal swelling values at the level of $\rho<$ 0,05 , while there was no significant difference between radial-, volumetric-swelling, radial-, longitudinal-, volumetric-shrinkage.

Significant differences were found between the some mechanical properties such as static bending strength, modulus of elasticity and Janka hardness (cross section, radial, tangential) of the Eucalyptus samples dried in ID and OD climates. On the other hand, it was found that drying climate had no significant effect on compression, tensile, dynamic bending and shear strength values.

Finally, in the light of the data obtained in this study, it is suggested to take into account the differences in chemical, morphological, physical and mechanical properties of Eucalyptus wood in drying process and solid usage areas.

\section{ACKNOWLEDGEMENTS}

This project was supported by the Kahramanmaras Sutcu Imam University, Research Project Coordination Unit, under project number 2018/2-55 M.

\section{REFERENCES}

ASTM. 2013. Standard test method for ethanol-toluene solubility of wood. ASTM D1107-96. ASTM: Pennsylvania, USA. https://www.astm.org/Standard/standards-and-publications.html

As, N.; Koc, K.H.; Dogu, D.; Atik, C.; Aksu, B.; Erdinler, S. 2001. Türkiye'de yetişen endüstriyel öneme sahip ağaçların anatomik, fiziksel, mekanik ve kimyasal özellikleri (in Turkish). İstanbul Üniversitesi Orman Fakültesi Dergisi 51(1): 71-88. https://dergipark.org.tr/tr/download/article-file/176141

Aslan, S.; Demetci, E.; Sozen, R.; Ilter, E.; Balkiz, O.D. 2008. Okaliptüs (Eucalyptus camaldulensis Dehn.) odununun bazı fiziksel, kimyasal, mekanik ve anatomik özellikleri (in Turkish). In: Proceeding of the $1^{\text {st }}$ Ulusal Okaliptüs Sempozyumu, Tarsus, Turkey. pp. 151-161. https://doa.ogm.gov.tr/Yayinlar/Muhtelif\%20 Yay\%C4\%B1nlar/DOA-\%20Okaliptus\%20Sempozyumu\%20Bildiriler\%20Kitab\%C4\%B1.pdf

Ay, N.; Topaloglu, E.; Tan, H. 2008. Okaliptüs (Eucalyptus camaldulensis Dehn.) odununun bazı fiziksel, mekanik özellikleri ve kullanım alanları (in Turkish). In Proceeding of the $1^{\text {st }}$ Ulusal Okaliptüs Sempozyumu, Tarsus, Turkey. pp. 78-83. https://doa.ogm.gov.tr/Yayinlar/Muhtelif\%20Yay\%C4\%B1nlar/DOA-\%20 Okaliptus\%20Sempozyumu\%20Bildiriler\%20Kitab\%C4\%B1.pdf

Ayata, U. 2008. Okaliptüs (Eucalyptus camaldulensis ve Eucalyptus grandis)'ün odun özellikleri ve kağıt endüstrisinde kullanımının araştırılması (in Turkish). Master Thesis, Kahramanmaras Sutcu Imam University, Kahramanmaraş, Turkey. https://tez.yok.gov.tr/UlusalTezMerkezi/TezGoster?key=biL2P3cCsPgUNjVdV2B sGKm0Sp-Sd7lOMSYMktjCr3Z2PjWVVxs_TWNvyhBtfvmD

Aytin, A.; Korkut, S.; As, N.; Unsal, O.; Gunduz, G. 2015. Effect of heat treatment of wild cherry wood on abrasion resistance and withdrawal capacity of screws. Drvna 66(4): 297-303. https://hrcak.srce.hr/ file/221880

Baranski, J.; Wierzbowski, M.; Konopka, A. 2014. The change of mechanical properties of selected wood species after drying process under various conditions $S G G W$ 86: 13-17. https://mostwiedzy.pl/en/ 
publication/the-change-of-mechanical-properties-of-selected-wood-species-after-drying-process-undervarious-cond,130751-1

Bektas, I.; Alma, M.H.; Bal, B.C.; Ayata, U. 2008. Okaliptüs (Eucalyptus grandis W. Hill. ) odununun dinamik eğilme direncinin belirlenmesi ve bazı ağaç türleri ile karşılaştırılması (in Turkish). In Proceeding of the $1^{\text {st }}$ Ulusal Okaliptüs Sempozyumu, Tarsus, Turkey. pp. 274-280. https://doa.ogm.gov.tr/Yayinlar/ Muhtelif\%20Yay\%C4\%B1nlar/DOA-\%20Okaliptus\%20Sempozyumu\%20Bildiriler\%20Kitab\%C4\%B1.pdf

Bektas, I.; Kilic Ak, A.; Cicekler, M.; Tutus, A. 2017. Effects of different drying environments on the dimensional stability of Eucalyptus wood. In Proceeding of the International Symposium on New Horizons in Forestry (ISFOR), Isparta, Turkey. pp. 334-336. http://ormanweb.isparta.edu.tr/isfor2017/documents/pdf/334. pdf

Bergman, R. 2021. Drying and control of moisture content and dimensional changes. Wood handbook: wood as an engineering material: Chapter 13. Centennial ed. General technical report FPL; GTR-190. Madison, WI: US Dept. of Agriculture, Forest Service, Forest Products Laboratory, p. 13.1-13.20. https://www.fpl.fs.fed. us/documnts/fplgtr/fplgtr282/chapter_13_fpl_gtr282.pdf

Bhat, K.M.; Bhat, K.V.; Dhamodaran, T.K. 1990. Wood density and fiber length of Eucalyptus grandis grown in Kerala. Wood Fiber Sci 22(1): 54-61. https://wfs.swst.org/index.php/wfs/article/view/1862

Bown, H.E.; Lasserre, J. 2015. An air-drying model for piled logs of Eucalyptus globulus and Eucalyptus nitens in Chile. New Zealand Journal of Science 45(1): 1-9. https://link.springer.com/content/pdf/10.1186/ s40490-015-0047-6.pdf

Bozkurt, A.Y.; Goker, Y. 1996. Fiziksel ve mekanik ağaç teknolojisi (in Turkish). İstanbul Üniversitesi, Orman Fakültesi Yayınları, Yayın No: 436, Istanbul, Turkey. ISBN 9754044201. https://www.worldcat.org/ title/fiziksel-ve-mekanik-agac-teknolojisi-ders-kitab/oclc/192012408

Cetin, F.; Gunduz, G. 2016. Türkiye'deki bazı ağaç türü odunlarının fiziksel özellikleri üzerine yapılan araștırmaların değerlendirilmesi (in Turkish). Bartın Orman Fakültesi Dergisi 8(2): 175-193. https://dergipark. org.tr/tr/download/article-file/272873

Cetin, F.; Gunduz, G. 2017. Türkiye'deki bazı ağaç türü odunlarının mekanik özellikleri üzerine yapılan araștırmaların değerlendirilmesi (in Turkish). Bartın Orman Fakültesi Dergisi 19(1): 161-181. https://dergipark.org.tr/en/download/article-file/302267

Dackermann, U.; Elsener, R.; Li, J.; Crews, K. 2016. A comparative study of using static and ultrasonic material testing methods to determine the anisotropic material properties of wood. Constr Build Mater 102(2): 963-976. https://www.sciencedirect.com/science/article/pii/S0950061815302178

Dahl, K.B.; Malo, K.A. 2009. Planar strain measurements on wood specimens. Experimental Mechanics 49: 575-586. https://doi.org/10.1007/s11340-008-9162-0

Davis, P.H. 1988. Flora of Turkey and the East Aegean Islands - Vol: 10. Edinburgh University Press: Edinburgh, Scotland, United Kingdom. https://www.amazon.com/Flora-Turkey-10-Aegean-Islands/ $\mathrm{dp} / 0852245599$

Duzkale, G.; Bektas, I.; Tunc, H.H.; Doganlar, Y. 2014. Zeytin ağacı (Olea Europaea) odununun bazı fiziksel ve mekanik özelliklerinin belirlenmesi (in Turkish). Ormancılık Dergisi 10(2): 29-35. https://dergipark. org.tr/en/download/article-file/272118

Forest Products Laboratory. 1999. Air drying of lumber. Gen. Tech. Rep. FPL-GTR-117. Madison, WI: U.S. Department of Agriculture, Forest Service, Forest Products Laboratory. 62 p. https://www.fpl.fs.fed.us/ documnts/fplgtr/fplgtr117.pdf

Gurboy, B.; Ozden, O. 1994. E. camaldulensis ve E. grandis odununun hacim-ağırlık değerleri ve lif morfolojisi (in Turkish). İstanbul Üniversitesi Orman Fakültesi Dergisi 44(1): 101-109. https://dergipark.org. tr/tr/download/article-file/176620 
Kantay, R. 1993. Kereste kurutma ve buharlama. Yayın 6. Ormancılık Eğitim ve Kültür Vakfı: Istanbul, Turkey. https://www.nadirkitap.com/kereste-kurutma-ve-buharlama-ramazan-kantay-kitap3189376.html

Karsavuran, Y.; Ayvaz, A.; Doganlar, M. 2008. Okaliptüste zararlı olan Leptocybe invasa Fisher and La Salle ve Ophelimus maskelli (Ashmead) (Hym.: Eulophidae)'nin Muğla ili'nde yayılışı (in Turkish). Ege Univ Ziraat Fak Derg 45(2): 91-94. https://dergipark.org.tr/tr/download/article-file/59283

KilicAk,A.2016. Okaliptüs kerestesinin doğal kurutma şartları üzerine denemeler:Kahramanmaraşiliörneği (in Turkish). Master Thesis, Kahramanmaras Sutcu Imam University, Kahramanmaras, Turkey. https://tez.yok. gov.tr/UlusalTezMerkezi/TezGoster?key=cbOXH84ZayrLjc0tI-QXKsJJChjMEmY2LWn2Qb57c9BwlyjP-b6BDJLBirvKL7M

Kocaefe, D.; Poncsak S.; Boluk, Y. 2008. Effect of thermal treatment on the chemical composition and mechanical properties of birch and apsen. Bioresources 3(2): 517-537. https://ojs.cnr.ncsu.edu/index.php/ BioRes/article/view/BioRes_03_2_Kocaefe_PB_ThermalTreatment_Birch_Aspen/199

Korkut, S.; Korkut, D.S.; Bekar, I. 2008. Okaliptüs (Eucalyptus camaldulensis Dehn.) odununun bazı teknolojik özellikleri üzerine 1sıl işlemin etkisi (in Turkish). In: Proceeding of the $1^{\text {st }}$ Ulusal Okaliptüs Sempozyumu, Tarsus, Turkey. pp. 209-214. https://doa.ogm.gov.tr/Yayinlar/Muhtelif\%20Yay\%C4\%B1nlar/ DOA-\%20Okaliptus\%20Sempozyumu\%20Bildiriler\%20Kitab\%C4\%B1.pdf

Kurschner, K.; Hoffer, A. 1969. Ein neues verfahren zur bestimmung der zellulose (in German). Technol und Chemie der Pap Zellstoff- Fabrikation 26: 125-139.

Lahr F.A.R.; Nogueira M.C.; De Araujo, V.A.; Vasconcelos, J.S.; Christoforo, A.L. 2018. Wood utilization of Eucalyptus grandis in structural elements: Densities and mechanical properties. Engenharia Agrícola 38(5): 642-647. https://doi.org/10.1590/1809-4430-eng.agric.v38n5p642-647/2018

Lahr, F.A.R.; Nogueira, M.C.; De Araujo, V.A.; Vasconcelos, J.S.; Christoforo, A.L. 2017. Physical-mechanical characterization of Eucalyptus urophylla wood. Engenharia Agrícola 37(5): 900-906. https://doi.org/10.1590/1809-4430-eng.agric.v37n5p900-906/2017

Lima, I.L.; Longui, E.L.; Freitas, M.L.M.; Zanatto, A.C.S.; Zanata, M.; Florsheim, S. M. B.; Bortoletto, G. 2014. Physical-mechanical and anatomical characterization in 26-year-old Eucalyptus resinifera wood. Floresta Ambiente 21(1): 91-98. https://doi.org/10.4322/floram.2014.006

Nogueira, M.C.; Almeida, D.H.; Araujo, V.A.; Vasconcelos, J.S.; Christoforo, A.L.; Almeida, T.H.; Lahr, F.A.R. 2019. Physical and mechanical properties of Eucalyptus saligna wood for timber structures. Ambient constr 19(2): 233-239. https://doi.org/10.1590/s1678-86212019000200319

Nogueira, M.C.; De Araujo, V.A.; Vasconcelos, J.S.; Cruz, J.N.; Vasconcelos, J. C.S.; Prataviera, F.; Christoforo, A.L.; Lahr, F.A.R. 2018. Characterization of Eucalyptus maidenii timber for structural application: Physical and mechanical properties at two moisture conditions. South-east European forestry 9(2): 141-146. https://doi.org/10.15177/seefor.18-10

Ors, Y.; Keskin, H. 2008. A ̆gaç malzeme teknolojisi (in Turkish). Gazi Kitabevi: Ankara, Turkey. https://finalpazarlama.com/kitap/gazi-kitabevi/agac-malzeme-teknolojisi/010133777

Pettersen, R.C. 1984. The Chemical composition of wood. Chapter 2. In: The chemistry of solid wood. American Chemical Society: Madison, WI, USA. 57-126. https://www.fpl.fs.fed.us/documnts/pdf1984/ pette84a.pdf

Simpson,W.T.; Wang, X. 2004. Estimating air-drying times of small-diameter ponderosa pine and Douglas fir logs. Forest Prod J 54(12): 24-28. https://www.fpl.fs.fed.us/documnts/pdf2004/fpl_2004_simpson002.pdf

Sancak, S. 2010. Kızılcık (Cornus mas L.) odununun bazı fiziksel, mekanik ve teknolojik özelliklerinin belirlenmesi (in Turkish). Master Thesis, Kastamonu University, Kastamonu, Turkey. https://tez.yok. gov.tr/UlusalTezMerkezi/TezGoster?key=zD1B0cW7zVr3VcnZjitVXmXz9GnM8q66JMfip1nmLfqbqMHxf1xZVN8MevJJ63w 
TAPPI. 1999. TAPPI T203 cm-99: Alpha-, beta- and gamma-cellulose in pulp. TAPPI: Atlanta, USA.

TAPPI. 2008. TAPPI T207 cm-08: Water solubility of wood and pulp. TAPPI: Atlanta, USA.

TAPPI. 2015. TAPPI T222 om-15: Acid-insoluble lignin in wood and pulp. TAPPI: Atlanta, USA.

TAPPI. 2016. TAPPI T211 om-16: Ash in wood, pulp, paper and paperboard: combustion at $525{ }^{\circ} \mathrm{C}$. TAPPI: Atlanta, USA.

TAPPI. 2018. TAPPI T212 om-18: One percent sodium hydroxide solubility of wood and pulp. TAPPI: Atlanta, USA.

Trevisan, R.; Rosa, M.; Haselein, C.R.; Santini, E.J.; Gatto, D.A. 2017. Dimensões das fibras e sua relação com a idade de transição entre lenho juvenil e adulto de Eucalyptus grandis W. Hill ex maiden (in Portuguese). Cienc Florest 27(4): 1385-1393. http://dx.doi.org/10.5902/1980509830220

TSI. 1976. TS 2470: Wood - sampling methods and general requirements for physical and mechanical tests. TSE: Ankara, Turkey. https://intweb.tse.org.tr/Standard/Standard/StandardAra.aspx

TSI. 1976. TS 2472: Wood - determination of density for physical and mechanical tests. TSE: Ankara, Turkey. https://intweb.tse.org.tr/Standard/Standard/StandardAra.aspx

TSI. 1976. TS 2474: Wood - determination of ultimate strength in static bending. TSE: Ankara, Turkey. https://intweb.tse.org.tr/Standard/Standard/StandardAra.aspx

TSI. 1976. TS 2475: Wood - detemination of ultimate tensile stress parallel to grain. TSE: Ankara, Turkey. https://intweb.tse.org.tr/Standard/Standard/StandardAra.aspx

TSI. 1976. TS 2477: Wood - determination of impact bending strength. TSE: Ankara, Turkey. https://intweb.tse.org.tr/Standard/Standard/StandardAra.aspx

TSI. 1976. TS 2478: Wood - determination of modulus of elasticity in static bending. TSE: Ankara, Turkey. https://intweb.tse.org.tr/Standard/Standard/StandardAra.aspx

TSI. 1976. TS 2479: Wood - determination of static hardness. TSE: Ankara, Turkey. https://intweb.tse.org. tr/Standard/Standard/StandardAra.aspx

TSI. 1983. TS 4083: Wood - determination of radial and tangential shrinkage. TSE: Ankara, Turkey. https://intweb.tse.org.tr/Standard/Standard/StandardAra.aspx

TSI. 1983. TS 4084: Wood - determination of radial and tangential swelling. TSE: Ankara, Turkey. https:// intweb.tse.org.tr/Standard/Standard/StandardAra.aspx

TSI. 1983. TS 4085: Wood - determination of volumetric shrinkage. TSE: Ankara, Turkey. https://intweb. tse.org.tr/Standard/Standard/StandardAra.aspx

TSI. 1983. TS 4086: Wood - determination of volumetric swelling. TSE: Ankara, Turkey. https://intweb. tse.org.tr/Standard/Standard/StandardAra.aspx

TSI. 2012. TS 3459: Wood - determination of ultimate shearing stress parallel to grain. TSE: Ankara, Turkey. https://intweb.tse.org.tr/Standard/Standard/StandardAra.aspx

TSI. 2019. TS ISO 13061-17: Physical and mechanical properties of wood - Test methods for small clear wood specimens - Part 17: Determination of ultimate stress in compression parallel to grain. TSE: Ankara, Turkey. https://intweb.tse.org.tr/Standard/Standard/StandardAra.aspx

Wise, E.L.; Karl, H.L. 1962. Cellulose and hemicelluloses in pulp and paper science and technology. McGraw Hill Book Co: New York City, USA 
Yaltirik, F.; Efe, A. 1994. Dendroloji = gymnospermae - angiospermae (in Turkish). İstanbul Üniversitesi, Orman Fakültesi Yayınları: Istanbul, Turkey. Yayın No: 431. https://books.google.com.tr/books/about/ Dendroloji.html?id=fMF2MwEACAAJ\&redir_esc $=\mathrm{y}$ 